\title{
Substance Abuse Among Bannermen and Banner Self-perception: An Analysis of Qing Language Primers
}

\author{
YVES TRACHSEL \\ University of Zurich \\ Volume 15, 2018 \\ Special Issue: Manchu in Transregional History
}

Bannermen were a core element of the Qing dynasty and guaranteed their military grip on China. Yet the original image of the hardy warrior in time gave way to that of a drinking and impoverished parasite living off the court - a picture that lingers to this day. Despite the publication of groundbreaking work on banner society published in the last few years, many aspects of banner life still need to be examined in greater depth, such as how the bannermen themselves came to terms with the new changing conditions in their lives and how they perceived themselves. The portrayal of substance abuse among bannermen in Qing language primers allows for intruiging conclusions on the life of bannermen, their self-perception above all. A translation and analysis of these hitherto neglected sources reveal that their reputation as mere language textbooks consisting of set phrases is undeserved.

旗人的药物滥用和自我认知: 关于清代语言启蒙读物的分析

Yves Trachsel 正弘

苏黎世大学

摘要

旗人是清廷的中坚力量, 确保了清廷对中国的军事控制。然而, 旗人最初弓 马涃熟的战士形象逐渐让位于一种酗酒贫穷的蛙虫形象, 后者至今依然深入 人心。虽然近年出版了不少研究八旗社会的奠基之作, 但八旗生活的许多 方面——例如旗人是如何逐步适应新的人生境况、又是如何进行自我认知 的——这些问题都需要我们仔细的考量。清代语言启蒙读物中对于旗人滥用 药物的描绘, 为我们提供了一扇观察旗人日常生活和自我认知的有趣窗口。 我们在对一直以来被忽视的蒙学读物进行翻译和分析后发现, 将蒙学读物仅 仅视作含有不同词汇的语言课本这一观点是非常不当的。 
旗人的藥物濫用和自我認知：關於清代語言啟蒙讀物的分析

Yves Trachsel 正弘

蘇黎世大學

摘要

旗人是清廷的中堅力量, 確保了清廷對中國的軍事控制。然而, 旗人最初弓 馬嫻熟的戰士形象逐漸讓位於一種酗酒貧窮的蛙蟲形象, 後者至今依然深入 人心。雖然近年出版了不少研究八旗社會的奠基之作, 但八旗生活的許多 方面——例如旗人是如何逐步適應新的人生境況、又是如何進行自我認知 的——這些問題都需要我們仔細的考量。清代語言啟蒙讀物中對於旗人濫用 藥物的描繪，為我們提供了一扇觀察旗人日常生活和自我認知的有趣窗口。 我們在對一直以來被忽視的蒙學讀物進行翻譯和分析後發現, 將蒙學讀物僅 僅視作含有不同詞匯的語言課本這一觀點是非常不當的。

\section{Introduction}

Apart from their penchant for alcohol, their drinking and eating habits are extremely coarse, and they have taken on foolish behaviour. They do not know how to budget their money, they do not attend to their proper duties and shy away from toilsome work assignments. After getting their monthly stipends, they often gather to intoxicate themselves in local shops and they have used up all their money before the end of the day. After being fully inebriated they stumble in the streets and lie there without anyone taking any interest in them. There are numerous wine shops in the provincial capital, which are mostly run by Hui people from Shandong. Half of their [the bannermen's] pay as soldiers is spent this way. ${ }^{1}$

This citation from the Heilongiiang zhigao 黑龍江志稿 (Chronicles of Heilongjiang) ${ }^{2}$ for the late Qing about the eating and drinking habits of local bannermen ("Yinshi fengsu" 飲食風俗) is one among many sources illustrating the toll substance abuse took on their life and livelihood. The fact that this description made it into the section on eating and drinking habits illustrates that such behavior must have been a normal condition.

Bannermen $^{3}$ were members of a socio-military organization referred to as the Eight

1. 嗜酒之外, 飲饌極菲。然顓愚成性。不知計算且習於遊惰稍近勞力之役轍避不前。八旗兵丁領得月餉, 每三 五成群, 甘飲市肆, 一日未終, 馨諸所有。而後已醉, 則隨路倒臥, 亦無人過問之. 省城酒肆極多, 大率山 東回民執此為業。練兵館項半耗於此矣.

2. Zhang Boying 張伯英 and Wan Fulin 萬福麟, Heilongjiang zhigao 黑龍江志稿 (Beiping: Wenhai chubanshe, 1932), 6:664.

3. The terms bannermen and Manchu are used somewhat interchangeably in this paper. This is due to the fact that the Eight Banners exerted a profound influence on Qing society throughout the Qing period, and bannerman became one, if not the, most striking marker of identity for a Manchu. This is also clearly discernible in the primers, where being Manchu is 
Banners (jakūn güsa). The Jurchen chieftain Nurhaci (r. 1616-1626) had founded the Eight Banners on the model of earlier hunting groups referred to as 'arrows' (niru) and arranged the whole Jurchen population in socio-military units that could be easily organized. This was considered the decisive factor in the successful conquest of Ming China and the ensuing foundation of the Qing dynasty. The Banner system was not only the pillar of Qing rule and as such vital to its military grip on the whole of China, but it also came to be the hallmark of Manchu identity in the course of the dynasty. In time, however, the banner system was confronted with serious challenges. Indebtedness and general impoverishment among bannermen became a major issue. ${ }^{4}$ Apart from the "occupational ban" ${ }^{5}$ which is often cited as the main reason for this, some sources, which I will present in this paper, suggest that excessive drinking was also responsible for the financial ruin of many bannermen.

Although the last three decades have seen the publication of several outstanding works about the bannermen and their lives, such as Mark C. Elliott's The Manchu Way (2001), Pamela Kyle Crossley's Orphan Warriors (1990), and Liu Xiaomeng's 刘小萌 Qingdai Beijing qiren shehui 清代北京旗人社会 (2008), none of these works treated in depth the influence of alcohol drinking and tobacco smoking on banner life. Furthermore, none included a detailed analysis of Manchu primers as historical sources. The goal of the paper is thus to take a tentative step in this direction and establish how alcohol drinking and tobacco smoking are represented in primers and what conclusions can be drawn from this presentation regarding the social life of the bannermen and how they perceived themselves and their lives. I will tackle this task with a thorough translation ${ }^{6}$ and analysis of a series of dialogues taken from Qing language primers, a genre that has received no structural text criticism so far and contains numerous dialogues about the aforementioned two topics.

The genre of primers ${ }^{7}$ can be divided into relatively formal primers on the one hand, and "word snippets" (bua tiaozi 話條子) on the other. An example for the former is

equivalent to being a member of the Eight Banners. See Mark C. Elliott, The Manchu Way: The Eight Banners and Ethnic Identity in Late Imperial China (Stanford: Stanford University Press, 2001). In the dialogues analysed here, the word age is also used to refer to bannermen.

4. This problem is commonly referred to as the "Problem of the Eight Banner Livelihood" (baqi shengji wenti 八旗生計問 題). Elliott, The Manchu Way, 196.

5. Bannermen were forbidden from pursuing other means livelihood other than being soldiers or officials, which made them financially dependent on the court. As a result, the strain on the imperial treasury was immense. This regulation was not lifted until 1863, and its elimination contributed little to improving most bannermen's finances. In the last few decades of the dynasty, bannermen had acquired a bad reputation for merely living off the pensions and grain provided by the court. By that time, the economically deflated but egotistically inflated bannermen had already become a stock character of popular literature. See Pamela Kyle Crossley, Orphan Warriors: Three Manchu Generations and the End of the Qing World (Princeton: Princeton University Press, 1990), 176.

6. In cases where a too literate translation would have impeded comprehension, I have opted for a freer rendering into English.

7. For a more detailed and well-structured introduction into the history of this genre please refer to: Tatjana A. Pang, Schriftliche mandschurische Quellen zur Geschichte und Kultur des Qing-Reiches des 17. und 18. Jahrhunderts (Wiesbaden: Harrassowitz Verlag, 2015), 124-36. 
the Da Qing quan shu 大清全書 (The Complete Book of the Daicing Dynasty) consisting of fourteen fascicles in total, completed by the scholar Shen Qiliang 沈啟亮 (fl. 16451693) in the 1683. The last fascicle of this work contained an appendix named Qingwen zhinan 清文指南 (Compass of the Manchu Language), split into a discussion of the Manchu alphabet, a collection of sample sentences, a collection of language exercises, and lastly a grammar. This work also contained ten short dialogues about the daily life of the Manchu people, such as banner affiliation, family stories, table stories, etc., and can be considered the first Manchu primer. ${ }^{8}$ Other works followed in due time, among which the Tanggu Meyen (The Hundred Chapters) and the Dehi Meyen (Forty Chapters) are the most noteworthy examples.

"Word snippets," on the other hand, are ad-hoc collections of dialogues, often compiled by the teachers themselves. ${ }^{9}$ These dialogues were rendered in a very colloquial and, frequently, highly entertaining style, not lacking the occasional heated argument and ensuing profanity. These works were employed on a daily basis at banner schools in order to familiarize young bannermen with the spoken Manchu language, and as a result contain dialogues based on events in the real life of the bannermen. ${ }^{10}$ The texts were recited together with the teacher and normally one such work was studied for one school year. There can be no gainsaying that the more formal primers partially served as models for these "word snippets." However, teachers - especially teachers at private schools - also added their own material. ${ }^{11}$ Given the fact that the episodes in the "word snippets" mirrored the lives of the bannermen, it is to be expected that they contain more insight into the daily life of the young bannermen and banner society in general, insight that can hardly be found in official records issued by the court.

After some information about the corpus, I present essential background information on the history and usage of alcohol and tobacco by the Manchus. I then elaborate on the noteworthy characteristics of each relevant dialogue found in the primers in the two sections on alcohol and tobacco in Manchu culture. The end of each section contains a short summary of the findings in the dialogues. Lastly, I put all the findings in their respective contexts and draw conclusions.

\section{Corpus}

The corpus consists of five mostly bilingual Manchu-Chinese manuscripts, which are part of a larger collection of Manchu primers referred to as "Gesprächsbücher" (con-

8. Pang, Mandschurische Quellen, 129.

9. Aixin Jueluo Yingsheng 爱新觉罗瀛生, “Tantan Qingdai de Manyu jiaoxue” 谈谈清代的满语教学, Minzu yanjiu 满族 研究 1990.3: 45.

10. Aixin Jueluo, "Tantan Qingdai de Manyu jiaoxue," 45.

11. Aixin Jueluo, "Tantan Qingdai de Manyu jiaoxue," 45. 
versation books) in the catalog, and other manuscripts belonging to the Staatsbibliothek zu Berlin. These manuscripts are part of the Collection Polevoj ${ }^{12}$ consisting of approximately 150 mostly Manchu and Mongolian manuscripts that have been digitized within the framework of an ongoing digitization of the library's collection. Information about dating and authorship is scarce in the primers. One dating in Primer 3 (Hs. or. 8440 ) goes back to 1858 (the 8 th year of Xianfeng). Since the other primers I analyzed are to a great degree identical in content and structure, I propose that they were compiled around the same time. The other two datings in Primer 1 (Hs. or. 8399), which is a monolingual Manchu copy of the Qingwen zhiyao 清文指要, go back to the years 1847 and 1848 (27th and 28th years of Daoguang) and merely indicate the time when the students were finished reading the manuscript in class. ${ }^{13}$ The original Qingwen zhiyao was compiled in 1809 . There is also no definite way of knowing whether the bannermen in the dialogues were based in Beijing or in one of the garrisons across the country. The mention of some hutongs in other primers, however, suggests that at least some of them lived in the capital. The primers in question have been chosen mainly due to their numerous mentions of alcohol and tobacco consumption. Since they exhibit the typical characteristics of primers, they can undoubtedly be considered representative works of this genre. ${ }^{14}$ Lastly, I believe that the primers in question, the copy of the Qingwen zhiyao being the only exception, belong to the second, ad-hoc type of primers, the "word snippets." However, I will refer to them as "primers" throughout the paper for the sake of simplicity.

\section{Alcohol in Manchu Culture}

Alcohol has been a very popular consumable good in the native region of the Manchus for a long time due to cold winter temperatures and traditional herding lifestyles which shaped consumption patterns. ${ }^{15}$ Alcohol served various purposes in the lives of the Manchu people, for instance as a sacrificial offering to their gods and ancestors. ${ }^{16}$ As is well known, Manchus sometimes drank to excess, which in time prompted stern

12. For the complete collection, please refer to Hartmut Walravens, Chinesische und mandjurische Handschriften und seltene Drucke (Stuttgart: Franz Steiner Verlag, 2009). The digitized manuscripts are available in the online catalogue of the Staatsbibliothek zu Berlin https://digital.staatsbibliothek-berlin.de/.

13. Doro Eldengge i juwan nadaci aniya omšon biya de hülame wajiha and Doro Eldengge i juwan jaküci aniya biyai juwan duin de hülame wajiha.

14. I am currently preparing an integral translation and critical edition of all the primers in the Staatsbibliothek zu Berlin, forthcoming in early 2019 (Manchu Foundation Publishing). This project enables me to examine an increased quantity of primers, a task which I was not able to fulfill in the paper at hand given the limited space.

15. Norman Smith, Intoxicating Manchuria: Alcohol, Opium, and Culture in China's Northeast (Vancouver: UBC Press, 2012), 23.

16. Chen Jianwei 陈见微, “Qingdai Dongbei minjian de jiu wenhua” 清代东北民间的酒文化, Jilin shifan xueyuan xuebao 吉林师范学院学报 1996.1: 19. 
reactions from the ruling class. Nurhaci already perceived alcohol as a threat to the discipline and health of his subjects and issued an edict banning its excessive consumption. The drinking problem of bannermen, however, proved to be a constant and vexing problem for the court. An edict by the Yongzheng emperor (r. 1722-1735) treated this subject: "Among Eight Banner officers and soldiers are many who drink and drink and get so intoxicated that their appearance [permanently] changes. Taking life as a lark, they lose all their property and behave wildly and disgracefully . . . . I feel sorry and pity these people, and desire that they . . . be given a year or two to reform their ways." 17 The emperor obviously bemoaned the self-indulgent behavior of some bannermen, which failed to conform to the manly virtues ${ }^{18}$ that the court was propagating. Drinking was by no means exclusive to bannermen, and the Chinese majority is also known to have indulged in it. ${ }^{19}$ However, the court was preoccupied with inebriated bannermen because it was responsible for their livelihood and assisted them when they found themselves in financial predicaments. ${ }^{20}$ As noted above, excessive drinking was often considered to have caused or exacerbated financial difficulties.

Literary works of the time, such as the Emu Tanggù Orin Sakda-i Gisun Sarkiyan (Erzählungen der 120 Alten, hereafter 120 Tales) rendered into German by Giovanny Stary, also treated the subject of drinking. In a passage from 120 Tales, one of the elders tells the story of a company leader who noticed that several hundred families were living a hard life because they spent a considerable amount of their money on alcohol. ${ }^{21}$ He called on the people in the company to make some drastic changes and, after they paid heed to his advice, their lives improved again. ${ }^{22}$ There is another mention in the 120 Tales $^{23}$ of the destructiveness of alcohol and its negative influence on the livelihood of people:

17. Yongzheng Emperor 雍正, “Shizongxian huangdi shangyu baqi” 世宗憲皇帝上諭八旗, last accessed March 10, 2018, https://ctext.org/wiki.pl?if=gb\&chapter=899596\&searchu=\%E9\%85\%92.

上諭比見八旗官員兵丁内嗜酒沈湎以致面貌改常輕生破産肆行妄為者甚衆其中豈乏才具可用之人朕實憫 之惜之 $[\ldots]$ 酗酒不肖之徒給限一年或二年令其悛改.

18. This policy is commonly referred to as the Manchu Way (guoyu qishe 國語騎射) which the court vigorously promoted in the eighteenth century and to a lesser extent later on. Elliott, The Manchu Way, 8.

19. The existence of sects among the Han population which prided themselves on their abstention from meat, tobacco, and alcohol clearly shows that drinking and smoking lacking in moderation was also widespread among the Chinese population. The Jindan sect, for instance, was well-established in China and enjoyed a wide following in Rehe. Also the Zaili sect, which flourished in Zhili, celebrated abstention from opium, alcohol, and tobacco. Cecily McCaffrey, "From Chaos to a New Order: Rebellion and Ethnic Regulation in Late Qing Inner Mongolia," Modern China 37.5 (September 2011): 538.

Gina Hames writes that Buddhism played a crucial role across Chinese history in curbing excessive drinking that had been a problem in the pre-Buddhist period. Alcohol in World History (London: Routledge, 2012), 29-30.

Though this may have been true for a certain time, Susan Naquin and Evelyn S. Rawski write that alcohol had become a part of the diet of most people in China by the eighteenth century. Chinese Society in the Eighteenth Century (New Haven: Yale University Press, 1987), 74.

20. Elliott, The Manchu Way, 193.

21. Giovanni Stary, Emu Tanggū Orin Sakda-i Gisun Sarkiyan - Erzählungen der 120 Alten (Wiesbaden: Harrassowitz Verlag, 1983), 95-96.

22. Stary, Sakda, 96-97.

23. Stary, Sakda, 116-17. 
All bad and evil things start with liquor. Only ignorant people say unreasonable things like that they need grain to distill liquor .... In the bigger and smaller prefectures, subprefectures, districts, and counties there aren't merely three or four distilleries, but more than ten, more than twenty, even more than thirty or forty! In the subprefecture governed by the subprefect of Köke Qota alone, there are more than three hundred distilleries. In such a shop you need, if business is slow, at least four to five hule ${ }^{24}$ a day, and if business is thriving to the highest degree, ten or even more bule of grain to distil liquor. One big hule of grain is sufficient to feed 400 people for a whole day. And this amount of grain is processed to liquor in one instant. ${ }^{25}$

The pedagogical message of these episodes is all too obvious, but the ideal outcome in these short stories seems to be more fiction than reality. The diary written by the soldier Dzengšeo (1652-1712) illustrates that drinking was also perceived as a problem in the Eight Banners during military campaigns: "On the twentieth, since [people were] enjoying themselves spending money, drinking alcohol, and not wearing swords, Lieutenant-general Hife issued an order to the effect that those caught [in these malfeasances] would be punished." ${ }^{26}$

Lastly, it bears mentioning that the practice of excessive drinking was closely related to Qing-dynasty teahouse culture. The local teahouses came to feature among bannermen's favorite places of leisure ${ }^{27}$ and they were the place-to-be for bannermen after their morning walks or bird breeding. ${ }^{28}$ Their main habits were drinking tea in the morning, alcohol during the latter half of the day, and smoking after meals. ${ }^{29}$ This trend of spending time in teahouses became even more serious in the late Qing when many bannermen were stripped of their posts and found themselves without any occupation.

\section{Drinking 1}

Primer 5 (Hs. or. 8463), Page 28-30

The first dialogue is between a bannerman with a heavy cough and a fellow banner-

24. A measure of volume equaling ten lesser pecks, a bushel. Jerry Norman, A Comprehensive Manchu-English Dictionary (Cambridge, Mass.: Harvard University Asia Center, 2013), 183.

25. Ehe gusherakü baita yooni arki ci deribumbi kai. Sarkū niyalma damu arki burara de giyanakū udu jeku baibumbi sembi. Te bici fu, ting, jeo, hiyan-i ba amba ajige adali akū, bisire arki burara puseli absi akū ilan duin ci juwan udu orin udu güsin dehi funceme bisirengge gemu bi. Hubu hoton-i uhei saraci-i kadalaha emu ting ni harangga teile arki burara puseli uthai ilan tanggü funceme bi. Puseli tome inenggidari komso ocibe, duin sunja bule ci wesibun, juwan udu hule ci fusihïn jeku be baitalame arki burambi, етu amba hule-i jeku heo seme duin tanggü niyalmai emu inenggi ergen hetumbure de tesumbi.

26. Nicola Di Cosmo, The Diary of a Manchu Soldier in Seventeenth-Century China: My Service in the Army, by Dzengšeo (London: Routledge, 2006), 92.

Orin de gūsai ejen hife. jiha eifire. arki nure omire. loho asharakū oci. nambuha be tuwame weile arambi seme fafulaha. 27. Liu Xiaomeng, Qingdai Beijing qiren shehui (Beijing: Zhongguo shehui kexue chubanshe, 2008), 642.

28. For more insight into the daily leisure of the bannermen, see Lao She 老舍 (1899-1966), Zheng hongqi xia 正紅旗下 (Tianjin: Tianjin renmin chubanshe, 2017).

29. Liu, Qiren, 642. 
man who presents him with advice on how to cure it. Already in the very first lines of this dialogue, drinking is portrayed as negative, and excessive alcohol consumption is quickly identified as the reason for the age's bad cough. ${ }^{30}$ The moral message is not long in coming: The coughing bannermen is advised to cut back on his alcohol intake or stop drinking altogether: "We people should cherish our lives. Liquor isn't worth dying for" (Niyalma seme jalan de banjifi, ergen haji dabala, arki de ergen susaki sere niyalma geli bio?). After this moralistic lecture, however, the dialogue takes a twist and becomes rather entertaining. This is due to the sudden change of attitude in the drinking bannerman. When he is admonished for the first time that he should cut down on alcohol because it will only worsen his cough, he indirectly confesses to drinking by saying that he had not been drinking for a couple of days already. However, when he is admonished for a second time, he becomes irritated and starts denying any connection to liquor whatsoever: "What's that got to do with drinking anyway? How dare you!" (Omire de ai dalji? Ai geli.). This behavior seems rather typical for someone who has run out of arguments and as a result unmasks him as a drunkard. It is likely that the young bannermen studying this dialogue have witnessed such a conversation before, or even participated in one, and thus could relate to this situation.

A: Age, si fucihirayangge labdusaka.

B: Waka oci ai. Duleke biraci, kohong kohong seme fuciyahai. Ertele umai nakarakū.

A: Age, arki be majige targa. Ai sain jaka. Niyalma seme jalan de banjifi, ergen haji dabala, arki de ergen susaki sere niyalma geli bio?

B: Bi targaha. Omirakū oho. Targafi udu inenggi oho, sunja ninggun inenggi oho.

A: Umesi sain, eteme targa. Jai omici, ere jalan de banjire be ehe seme secina.

B: Omire de ai dalji? Ai geli!

A: Si bulekušeme tuwa. Arki de bešekebi.

B: Tuwara ba akū ohobi.

A: Kemuni arki de ai dalji sembi. Toktofi casi ${ }^{31}$ genembi.

A: Age, your cough is quite strong!

B: Tell me about it. I've been coughing like this since last month, and it hasn't stopped until now.

30. The correlation between coughing and alcohol intake is less well established in the West than in China, where even ordinary people have a basic grasp of traditional Chinese medicine and know that alcohol can increase inner body heat and therefore also cause coughing. The standard work on herbology in Chinese medicine, the Bencao gangmu 本草纲目 provides the following information for 米酒 (nure): [气味] 苦、甘、辛、大热、有毒. Li Shizhen 李时珍, Bencao gangmu (Beijing: Renin weisheng chubanshe, 1982), 1558.

31. The "there" (casi) is not explained in more detail, however I suggest that a teahouse or any other drinking establishment is being referred to. 
A: Age, you'd do good in cutting down a bit on liquor. What use is it anyway? We people should cherish our lives. Liquor isn't worth dying for.

B: I've already cut down completely on liquor, and I don't touch it anymore. It's been a couple of days now, five or six.

A: That's good, cut it down completely. Should you drink again, you can kiss your life goodbye.

B: What's that got to do with drinking anyway? How dare you!

A: Take a good look at the mirror, you're dead drunk!

B: Why should I take a look? There's no reason for that.

A: And yet you say, "What's that got to do with liquor?" I'm sure you keep going there.

\section{Drinking 2}

Primer 2 (Hs. or. 8430), Pages 24-26

The next dialogue contains a key utterance made by one age: "Are there people that don't drink in this day and age?" (Te $i$ forgon $i$ niyalma omiraküngge geli bio?) It was apparently considered odd if someone did not drink. This dialogue also shows the influence of peer pressure, because the age unwilling to drink at first obviously is allergic to alcohol but still ends up drinking. This results in his face turning red, a symptom of alcohol intolerance. This dialogue also suggests that alcohol seems to have played a vital role in bonding and establishing social relationships. Lastly, one bannerman also clearly differentiates between arki "liquor" and nure "rice wine," of which the latter is supposedly weaker as it is undistilled.

\section{A: Age, emu hüntahan omirakūn?}

$B$ : Bi omime bahanarakù.

A: Te i forgon i niyalma omiraküngge geli bio?

B: Yargiyan i ajige ci angga de gamarakù.

A: Ai geli! Arki waka, nure kai. Emu juwe hüntahan omire de aibi?

B: Yargiyan i omime bahanarakū. Bi geli holtombio?

A: Age ainaha bi? Ere emu hüntahan teile okini.

B: Tuttu oci, bi omiki.

A: Age juru omireo.

B: Bi yargiyan i muterakù. Si ojorakū. Hacihiyara jakade, bi araha akù omiha, si tuwa! Deregemu fularahabi.

A: Age unenggi muterakū oci, jai majige angga isireo.

B: Je, bi angga isiki.

A: Age, jai emu hüntahan omireo. 
B: Joobi isika. Akdarakū oci, si tuwa! Dartai uthai ojorakū ombi.

A: Tuttu oci, uthai joo.

A: Age, won't you drink a cup?

B: I can't drink.

A: Are there even people that don't drink in this day and age?

B: Not a drop has touched my lips since I was a child.

A: Unbelievable! But this isn't liquor, it's just rice wine. Where's the problem in drinking one or two cups?

B: I really can't touch that stuff. Do you think I'm trying to cheat you?

A: What's the matter with you? Just this one cup.

B: Well, alright, I'll drink it.

A: Age, why not drink both of them?

B: I really can't. You shouldn't pester me (shortly afterwards)

Now I've drank it all up myself because of your urging, look, my face is all red again!

A: You indeed can't drink. But still, have another go!

B: Aye, I'll have some more.

A: Age, drink another cup

B: Enough already! If you don't believe me, look [at my face]! I shouldn't drink for some time.

A: Well then, that's enough for now.

\section{Drinking 3}

Primer 3 (Hs. or. 8440), Pages 14-23

This rather lengthy dialogue illustrates once more how intense the social pressure concerning drinking must have been between bannermen. It is also informative about how a proper guest had to behave, namely that he should not lift his chopsticks and eat before the host touched his cup of liquor or wine. Also, there is yet again a medical component in this dialogue, and it is safe to assume that the age used to drinking has already developed a solid alcohol addiction, which is illustrated by the following utterance: "But I've always been drinking like this, I'm afraid I can't stop all of a sudden" (Damu bi seibeni omime taciha, етu erinde targame muterakī ojorahü). The other age also advises him to cut back on his alcohol intake but not to stop drinking altogether because this may be unhealthy and possibly cause withdrawal symptoms. He then enquires whether the age feels sick in the morning, which the latter denies. I assume that this is because the first age wants to evaluate whether the other age is already used to 
greater amounts of alcohol and whether he is in fact addicted. The host also expresses the wish that his servants should not be given alcohol, as they would no longer be able to perform their duties.

A: Eljitu, nure tebu. Ere emu hüntahan nure bi simbe kudulehengge. Si urunakù facihiyame omi.

B: Ai geli! Si damu mimbe takambio? Inu güwa agesa de kudulecina.

A: Mimbe ume hacihiyara! Bi serengge omihai soktoro de isinarakū oci, inu nakarakù sere niyalma kai. Geren agesa suwe inu udu hüntahan omicina. Ainu gemu uttu antahašara mangga ni?

B: Si serengge boihoji niyalma kai! Si jeterakù oqi, antaha inu omirakū secina?

A: Bi ainu jeterakū. Esi jeci, suwe emgeri jihe be dahame, giyan i jetere bade oci, uthai ebitele jefu! Omici acara bade oci, uthai soktotolo omi, teni inu dabala. Ere gese gocishüdame bai tefi, darabuha seme umai omirakū inu sabkalaraküngge, ainci mini nure hatan akün? Sogi booha amtangga akün aise.

B: Be age sini darabure be baiburakū. Gemu ubade jembi omimbi kai. Eljitu aba? Morin dahalara urse de nure omibu buda ulebu!

A: Ayaya! Meni booi niyalma de ume nure omibure. Ce gemu omime bahanarakù. Tumen de emgeri soktoho sehede, adarame membe dahalabumbi?

$B$ : Suwe mujilen sinda, hüwanggiyarakū.

B: Bi damu cembe labdu omiburakù oci uthai sain.

A: Age si seibeni daci nure omire mangga niyalma bihe kai. Enenggi ainaha ni? Umai omirakū.

B: Si sarkū. Bi neneme majige omihabi. Akū bihe bici, uthai mimbe emu inenggi šun tuhetele omibuha seme. Bi inu eimederakū. Buda jembi seci, bi yargiyan i sinde isirakū. Nure omiki seci, si minci cingkai eberi.

A: Tuttu sehe seme, si tere durun omici, buda jetere be tookambi sere anggala. Amaga inenggi se de oho manggi, urunakū tede kokirabumbi. Bi simbe tafulakahangge gemu saingisun. Akdambio akdarakù be sini ciha okini.

B: Ere gemu age mimbe gosihangge teni uttu jombure dabala. Gosirakū oci, ainaha seme ere gese gosihon gisun i tafularakü? Damu bi seibeni omime taciha, emu erinde targame muterakū ojorahū.

A: Tuttu waka. Si dabame omirakù oci, uthai sain. Hon targaha de neneme ehe ombi. Bi geli sinde fonjiki. Si nure omiha jai inenggi erde iliha manggi fuyakiyambio akün?

B: Fuyakiyahangge tuwara ba akv.

A: Tuttu oci, ere uthai nure i haran dere.

A: Eljitu, pour the wine. This cup of wine I will drink it in your honor. You have to drink it up quickly! 
B: Now what's that, I'm not the only person sitting here. Also drink in honor of the other ages here!

A: What's the rush? When it gets to me, I don't stop before I'm drunk anyway. Now, all of you, help yourselves to a few cups! Why are you being so polite and behaving like guests?

B: You're the host after all. If you don't eat, how can we even think of drinking?

A: Of course I'll eat. You've all come here after all. If you're supposed to eat, then eat your fill! If you're supposed to drink, then drink your fill as well! You're just sitting there modestly and don't even drink if you're offered something. And you don't even lift your chopsticks to eat. I guess my wine isn't strong enough for you and my plates not tasty enough!

B: Age, we don't need your urging, we'll all eat and drink. Where's Eljitu? Bring some wine and food to the stable lads!

A: Oh my! Don't give wine to the people of my estate! They're not used to drinking. What use will they be to us if they're drunk?

B: Don't worry, it'll be alright!

A: It's just that I don't let them drink too much.

B: Age, you've always been known to be a big drinker. What's with you today? You're not drinking at all.

A: You don't know. I actually drank a bit before. Otherwise I wouldn't mind drinking all day long until the sun sets. When it gets to eating, I am no match for you. But when it gets to drinking, you're not able to hold a candle to me!

A: That may be true, but if you drink like this, it will get in the way of your eating. As you grow older in years, it will prove harmful to your health. I really mean well with all these admonitions. Believe it or not!

B: I know that you only say these things because you're fond of me. If you weren't fond of me, you wouldn't take such pain in convincing me. But I've always been drinking like this, I'm afraid I can't stop all of a sudden.

A: Now that's not true. It would already be good if you didn't drink too much. But yes, it would be harmful too if you stopped drinking all at once. Let me ask you. Do you feel sick the morning after drinking wine?

B: Not that I know of.

A: If that's the case, then that's because of the wine [and your body is used to it]. 


\section{Drinking 4}

Primer 3 (Hs. or. 8440), Pages 27-28

The next dialogue illustrates the importance of alcohol, specifically wine, ${ }^{32}$ in sacrifices to the ancestors. At the same time there are also people sitting under a tree and drinking. Although it is not explicitly stated that they are drinking alcohol, it is reasonable to assume that they were not merely drinking tea or water.

A: Ere ucuri absi kumungge.

B: Haiki inenggi ojoro jakade, hoton ci waliyara niyalma ton aküngge tucike. Tuwaci sejen giyoo morin lorin umai lakqirakū yabumbi. Buda doboro nure hisalarangge inu bi. Boigon nonggire hoošan jih a deijirengge inu bi. Eifu i oyo be tenbeliyefi songgorongge songgoqombi. Mooi fejilen borhome tecefi omirengge omicambi.

A: There's really been a lot of commotion these days.

B: Because it's the Tomb-sweeping Festival, there are countless people leaving the city to go to the graves. Only look at the sedan chairs, the horses and the mules which are up and about on the streets. And there are also people sacrificing food and wine. And then there are also people carrying soil to the graves or burning joss money. There are groups of people hugging the graves and weeping and there are groups of people sitting in the shade of trees drinking.

\section{Drinking 5}

Primer 2 (Hs. or. 8430), Pages 31-32

The next two dialogues contain more information about how alcohol was considered a social problem in the Qing dynasty. They contain admonitions to stay away from alcohol and not to befriend people who are known to indulge in drinking. In these instances, alcohol is mentioned in the same breath as gambling, another widespread vice the court tried to counteract. The apparent moral message of these dialogues is thus that drinking does not conform to proper conduct, that is, the virtues a bannerman was supposed to uphold. In the first dialogue, the rather submissive tone of the student - despite frequenting the theater on a regular basis and having a penchant for drinking - suggests that he is rather young.

32. Lü Ping 吕萍 points out that although liquor gained popularity among the Manchus after the reign of the Kangxi emperor, they still preferred using rice wine for sacrificial purposes. Lü Ping, “Manzu saman jisi yu jiu” 满族萨满祭祀与 酒, Minzu yanjiu 2007.1: 103. 
A: Si mimbe simbe guwebu seci, si mini gisun be daha, uthai guwebure.

B: Sefu mimbe guwebuhe de, yaya hacin i baita okini, bi gemu sefu i gisun be dahara.

A: Ujui hacin, si ume uculere be donjire. Si aika hülhame donjici, bi werešeme bahafi donjiha sehede, simbe ainaha seme ja sindarakū. Jai hacin: weri sini baru aika jaka baisu seqi bici, uthai tucibufi inde bu. Ume niyalma be akabure. Ilaci hacin, si neneme nure omime bahanarakü bihe. Te adarame omime taciha. Ereci julesi targa. Jai omici ojorakū.

A: If you want me to forgive you, you have to follow my orders. Then you're forgiven.

B: Please forgive me, teacher, no matter what, I'll do everything you say!

A: Firstly, don't go listen to [theater] plays anymore. Should you still do that and I happen to get wind of it, I won't let you that easily off the hook anymore! Secondly, if someone wants something from you, just give it to them, don't fool them. Thirdly, you were not able to drink wine before, how come you started drinking like that in the first place? From now on you keep away from that stuff. You aren't allowed to drink anymore.

\section{Drinking 6}

Primer 2 (Hs. or. 8430), Pages 34-35

A: Tere niyalma umesi facuhün. Guculeci ojorakū.

B: Turgun adarame seci?

A: Tere inenggidari omimbime geli jiha efimbi. Emki efefi yabure gucu geli dembi jergi niyalma. Emke geterengge inu akū. Yabun fusihūn bime geli derakū. Ere gese niyalma geli guculeci ombio?

B: Dule ere niyalma uttu ni. Bi yargiyan i fuhali sarkū.

A: That guy's a mess! You shouldn't befriend him.

B: Why is that?

A: He drinks and gambles every day. And the friends he hangs around with are all people of the lowest kind. There is not a single one among them who's good for something. He's got poor moral conduct and knows no shame. Should one really be friends with a person like that?

B: So that's what kind of person he is, I really had no idea! 


\section{Drinking 7}

Primer 1 (Hs. or. 8399), Pages 51-54

This last dialogue presents us with an intoxicated banner servant who failed to perform his duties because of his excessive alcohol intake. Despite the pleadings of a third bannerman, his master is determined to punish him for his shortcomings. The lively dialogue is characterized by strong language such as, "I swear, today I'll beat him silly" (Enenggi fyartala tatarakù oci, bi uthai gashükini), and "good-for-nothing" (gusherakü fayangga), which provides a certain entertainment value.

A: Age si tuwa! Te geli isika! Lalanji omifi ilime toktorakù ohobi. Bi tere baita be si tede alahao akün seme fonjici heihedeme yasa durahün i mini baru gala alibumbi. Dutu hele ai geli waka. Jaburahüngge ainu? Ere gese niyalma be fanqaburengge geli bini? Enenggi fiyartala tatarakù oci, bi uthai gashükini.

B: Age, joo, ume! Ai ainci onggofi genehekū dere. Ini waka babe i endembio? Tuttu ofi, olhome jabume baharakù ohobi. Enenggi bi ubade bisire be dahame mini dere be tuwame, ere mari oncodofi guwebureo? Ereci julesi nure omire be eteme lashü lakini. Hendure balama. Kangnaci eihen ja, bungnaci aha ja sehe. Si soncoho jafaha jingkini ejen kai! I aibide ukcambi? Halaci halaha, aikabade halarakū kemuni uttu suihume omici, age i cihai i isebu. Bi udu jai ucaraha seme inu baire de mangga ombi.

A: Age si ainambahafi sara! Banitai emu gusherakü fayangga. Arki omimbi serede, uthai buqembi. Ini ama i senggi ci hono haji. Ere mudan guwebuhe de uthai halambi semeo? Mangga oci emu juwe inenggi subuhün dabala, dulehe manggi geli fe an i omimbi.

A: Age, look! He's had his fill again. He's dead drunk and can't even stand up straight. I asked him whether he delivered the message or not and he just staggered and reached out his hand to me. It's not like he's deaf-mute! Why doesn't he answer? People like this really make me angry. I swear, today I'll beat him silly!

B: Age, enough already! He probably forgot all about it and didn't go. Don't you think he knows that he messed up? He's probably too scared to answer. Can't you let it go this time for my sake? I'll make him stop drinking from now on. They're saying that riding a donkey is just as easy as bullying the weak! You're really a clueless master! Where has he gone now? If he really wants to change, then he should! If he doesn't change and keeps getting dead-drunk like this, you can punish him however you want. If I ever catch him like that again, I won't be able to help him out either.

A: Age, you really have no way of knowing. He's been a good-for-nothing ever since he was born. When it gets to alcohol, he's ready to die for it. He even cherishes it more than his father's blood! Do you think he'll change if you pardon him now? 
When it comes right down to it he'll be sober for a day or two but then he'll just keep drinking as usual.

\section{Summary}

In the dialogues above, alcohol was portrayed in different settings. In Dialogue 1, alcohol was portrayed as the cause of a health-related issue of one bannerman, who was advised not to drink anymore and presented with some advice on how to handle the symptoms. Despite the rather obvious moral message, the dialogue is also very entertaining due to the obstinate bannerman. In Dialogue 2, we see an example of peer pressure concerning drinking and a probable case of alcohol intolerance. Dialogue 3 shows us another example of peer pressure, but also a case of alcohol addiction. Furthermore, drinking is mentioned within the context of a meal. Dialogue 4 is about the function of alcohol in ancestor worship and its role during outings. In Dialogues 5 and 6, alcohol is portrayed as a social problem and mentioned in the same breath as gambling, another common vice of bannermen at the time. Dialogue 7 provides an example of how drinking hinders a servant in the fulfillment of his duties.

In all the dialogues except 5 and 6 , alcohol is presented as something negative that a bannerman needs to guard himself against. Since these dialogues are said to reflect banner life, the frequency with which excessive drinking is mentioned indeed suggests that it was rampant among different strata of society. Despite the negative depiction of drinking, the occasional altercations also exhibit a certain entertainment value, as the bannermen charged with drinking are (deliberately, in my view) portrayed as stereotypical drunkards for comic effect.

\section{Tobacco in Manchu Culture}

In addition to suggesting that heavy drinking was common among bannermen, these language primers also suggest that banner people smoked heavily, regardless of gender or social position. ${ }^{33}$ It is even suggested that Qing bannermen were agents for the wider dispersal of tobacco throughout other areas of China Proper after the conquest. The arrival of banner troops in Jiangnan restimulated the local tobacco industry, and by 1670 , tobacco was gradually appropriated by the Chinese upper gentry as well. ${ }^{34}$ According to the genealogist Fu Yiqiang (dates unknown), tobacco was "indispensable" for Manchu

33. Lucie Olivova, “Tobacco Smoking in Qing China,” Asia Major, 3d ser., 18.1 (2005): 227.

34. Carol Benedict, Golden-Silk Smoke: A History of Tobacco in China, 1550-2010 (Berkeley: University of California Press, 2011), 25. 
and Mongol bannermen in Sichuan, possibly because they believed it would protect them from malaria. ${ }^{35}$ A passage from the year 1630 in the Manwen laodang or Manbun rōtō 滿文老檔 (The Old Manchu Archives) - an indispensable source for events during the pre-dynastic and early dynastic period covering the years from 1607 to 1636 shows that the Manchus (or their predecessors, the Jurchen) knew of tobacco and most probably also smoked it, at least among the elite. In the following account, tobacco is listed as one of various exchange goods:

On the tenth day of the twelfth month, Batun Baksi, which had gone to Lio Uge in the Pi Doo village as a messenger, arrived. The tributary goods for the Emperor were 100 jin of tea, five jin of scents, 5,000 sewing needles, 200 pairs of yak horns, earrings for women, silk threads, 260 boxes of threads, and twenty taels of azurite. Batun Baksi was given thirty taels of silver, four (pieces of) silk, one raccoon dog fur coat, one bow, and fifty bundles of tobacco. ${ }^{36}$

The use of tobacco was banned by the Ming court for the first time in 1637 and was banned repeatedly thereafter. In 1639, the Manchu court in Shenyang banned it as well. Two years later, however, Hong Taiji (r. 1636-1643) admitted that the ban could not be enforced because Manchu princes continued to smoke in private, but he admonished that archery practice must not be neglected in favor of tobacco. ${ }^{37}$ Tobacco smoking quickly became common among all strata of society, an object of recreational consumption, so to say, which was not regarded as evil. ${ }^{38}$ From at least the seventeenth century on, Chinese doctors were well aware of the detrimental health effects of tobacco. However, tobacco was historically regarded as good for health in China, or at least not particularly harmful. ${ }^{39}$ Tobacco smoking was a ubiquitous phenomenon in Qing society, among both bannermen and the broader Chinese population. ${ }^{40}$ To what extent the bannermen actually smoked more than the Chinese majority, however, is hard to evaluate.

35. Benedict, Golden-Silk Smoke, 24.

36. Manbun rōtō 滿文老檔, ed. Kanda Nobuo 神田信夫 et al. (Tokyo: Tōyō bunko, 1955), vol. 2, 32:437.

Jorgon biyai juwan de, pi doo tun de lio uge de elcin genehe batun baksi isinjiha, han de unggihengge, cai emu tanggü gin, fun sunja gin, ulme sunja minggan, moo ihan i weihe juwe tanggü juru, ancun, sirge, tonggo juwe tanggü ninju hiyase, ši qing juwan yan, batun baksi de güsin yan menggun, suje duin, emu elbihe jibca, emu beri, dambagu susai kiyan, u iogi de emu suje buhe.

37. Alan Baumler, The Chinese and Opium under the Republic: Worse than Floods and Wild Beasts (Albany: State University of New York Press, 2007), 17.

38. Olivova, “Tobacco," 248.

39. Benedict, Golden-Silk Smoke, 252.

40. Benedict, Golden-Silk Smoke, 108. 


\section{Smoking 1}

Primer 2 (Hs. or. 8430), Pages 3-5

Akin to the first dialogue about drinking, this dialogue portrays smoking as an activity with detrimental effects on health. A bannerman with cracked lips is advised not to smoke for several days and to abstain from eating meat or sitting on a hot $k a n g,{ }^{41}$ as his companion quickly identified these habits as the main reason for his symptoms. This short conversation also comes with do-it-yourself-advice and reads like a case study out of a textbook on Chinese medicine.

Surprisingly, the moral undertone we previously encountered in the dialogues about drinking is entirely lacking. Perhaps this was because excessive smoking was less likely to ruin people's health and livelihood than drinking.

\section{A: Age, si dambagu omimbio?}

B: Bi omirakū. Angga nimembi. Ainaha erpenehebi?

A: Dere tuwa i haran kai. Dambagu be targaci sain. Ere sidende yali ume jetere. Šoyola. Juwe ilan inenggi šoyolaha manggi, inu cisui yebe ombi.

B: Baitakù muru akù. Bi dambagu yali be juwe ilan inenggi targaha. Umai yebe ojoro muru akū.

A: Si halhün nagan de ume dedure. Šahürun nagan de dedu. Dedure onggolo sun nimenggi be angga i femen de iju. Jai cimari uthai yebe ombi. Buyarame jaka be ume jetere. Buyarame jaka tuwa dekdembi.

B: Je, bi inenggi cendeme tuwaki.

A: Age, do you want a smoke?

B: No, I don't, my mouth hurts. How is it that my lips crack this badly?

A: I think that may be because of inner heat. It'd be good to give up smoking tobacco. And don't eat meat for a while and fast. After two or three days of fasting, it'll get better by itself.

B: It doesn't seem to be working. I've already avoided tobacco and meat for two or three days now. But there's no sign of improvement at all.

A: Don't lie on a heated kang; lie on a cold one instead. Before resting, apply some

41. This advice fits Chinese medical theory. Inner heat is one of the six pathological factors according to Chinese medicine: Yin Huihe 印会河, Zhongyi jichu lilun 中医基础理论 (Shanghai: Shanghai kexue jishu chubanshe, 2007), 93.

Tobacco, alcohol, and some kinds of meat are believed to increase inner body heat, which in time can lead to inflammation-related symptoms such as blisters, rashes, pimples, nervousness, anxiety, cracked lips, and the like: Harriet Beinfield and Efrem Korngold, Traditionelle Chinesische Medizin: Grundlagen, Typenlehre, Therapie (München: Deutscher Taschenbuch Verlag, 2009), 91-92. 
grease on your lips. The next morning it'll be better. Don't eat snacks, because they'll cause symptoms on your body again.

B: Aye, I'll give it a try.

\section{Smoking 2}

Primer 2 (Hs. or. 8430), Pages 27-28

The most noteworthy characteristic of this short dialogue is the exaggerated reaction of the bannerman who cannot locate his misplaced tobacco pipe bag. This dialogue, apart from familiarizing the bannermen with the most common words about smoking, was undoubtedly also added for entertainment purposes.

A: Bi ubade sindaha dambagu goqikü fadu be we gamaha? Minde tuciburakù oci, bi uthai balai toombi! Teni ubade sindaha jaka be uthai waliyabuha doro bio?

B: Si elheken i baicina! Ai uttu facihiyašambi?

A: Bi babade baifi gemu akv bade. Bi ainu faqihiyašarakū ni?

B: Ere dambagu goqikü fadu wakao? Bairakù bime uthai balai tooki sembi. Bi henduhekū. Si umesi oilohon.

A: Who took the tobacco pipe bag I had put here? If you don't bring it at once, I'll rant and rave! How can it be that something I had just put here has vanished all of a sudden?

B: Look for it calmly, what's there to get worked up about?

A: I've looked for it everywhere, it's gone! How can I not get worked up?

B: There, isn't this your tobacco pipe bag? You haven't even started looking properly and you're already throwing a tantrum! What a muddlehead you are!

\section{Smoking 3}

Primer 4 (Hs. or. 8460), Pages 36-38

This dialogue presents us with some information about how to properly stuff a tobacco pipe. Smoking is portrayed as a leisurely activity which can be very enjoyable if one pays attention to certain points, such as the length of the pipe, the dryness of the tobacco, and how to stuff and clean the pipe. As a result, this dialogue reads like a manual.

A: Age dambagu omime bahanambio?

B: Bahanambi. 
A: Dambagu tebufi gaju!

B: Si ainahabi?

A: Tere golmin dambagu gocikù de tebufi gaju! Ere foholon dambagu gocikū ašure de kušun kai. Gajikini sain. Yaya dambagu gocikū okini. Age mukiyehe dabufi gaju! Ere dambagu mukiyere mangga, geli mukiyehe! Yaha gaju!

B: Bi dabuki.

A: Emu dulere yaha be gaju! Ere dambagu derbehun dabuha seme darakv. Jai emu gocikù tebu! Niša i tebu! Dulimba be dabu! Dalba be dabuha manggi, ukiyehe seme singgiyatala. Emu mangga inu bahafi icanggai omirakù. Ere dambagu gocikù dolo sibuhabi. Hosori i qanggi ohobi. Saikan i dasatafi tebu.

A: Age, do you know how to smoke tobacco [properly]?

B: I do.

A: Then stuff the pipe and bring it.

B: What do you want to do?

A: Stuff that long tobacco pipe and bring it here! This short tobacco pipe feels awkward in the mouth. Please bring one. Any other tobacco pipe will do. If it's not burning anymore, light it again. The fire dies down so easily, [look], it burned down again! Bring me some charcoal.

B: Aye, I'll light it.

A: Bring some burning charcoal! This tobacco is so moist and almost impossible to light. Stuff another pipe. And make it a full one, especially the middle. If one stuffs the sides, it's almost impossible to draw the tobacco pipe, you get a sore mouth and it's not really enjoyable. This pipe there was actually clogged with tobacco tar; be sure to clean it out before you stuff it.

\section{Smoking 4}

Primer 2 (Hs. or. 8430), Pages 12-13

Lastly, in the next two dialogues tobacco consumption is mentioned as a simple way to kill time or is depicted as a potential stimulant after a meal.

A: Suwe neneme gene. Doogan de isinafi, mimbe aliyareo. Dambagu omire sidende, bi uthai amcame isinambi. Hüdukan i oso, ume emdubei aliyabure.

A: You guys can go first. Wait for me as soon as you have reached the bridge. Have a smoke in the meantime. I'll arrive afterwards. Be quick and don't let them wait too long! 


\section{Smoking 5}

Primer 3 (Hs. or. 8440), Page 11

A: Sun cai acabu. Dambagu tebufi benju.

A: Bring milk tea. Pack the pipe and bring it here.

\section{Summary}

In Dialogue 1, smoking is portrayed as a pastime with detrimental effects on health. Dialogue 2 is about the vexation of a bannerman who is unable to locate his tobacco pipe bag. Dialogue 3 is a manual on what to pay attention to when smoking. In Dialogue 4, smoking is portrayed as a mere way to kill time, and in Dialogue 5 smoking is mentioned as a stimulant when drinking tea or eating a meal.

The most striking point between the descriptions of drinking and smoking is that the latter lacks any moral undertone. Furthermore, smoking is only portrayed as unhealthy in Dialogue 1, compared to various such examples for drinking. Considering the frequency with which it occurs in the primers, smoking seems to have been fairly widespread among bannermen in different situations.

\section{Conclusion}

The frequency of alcohol-related dialogues is an indication that drinking indeed occupied an important position in the lives of the bannermen. This comes as little surprise, considering what relevant secondary sources say on this topic. Judging from some dialogues, this was also true for very young bannermen and servants. Drinking was thus not confined to any particular social stratum or age group. In the dialogues, drinking also played a vital role in social bonding. If a bannerman did not want to drink, he was regarded as odd, and a certain amount of peer pressure was used to make him drink. At the same time, drinking is portrayed as something negative and unhealthy, and people who are known to indulge in excessive drinking are persuaded to do otherwise or shunned.

Why are these dialogues in the primers in such large numbers? Were they added to transmit a moral message? In part, yes. Their target audience undoubtedly consisted of younger bannermen who were studying Manchu with these materials, which, as mentioned, were often compiled by teachers themselves. It it thus reasonable to assume that a teacher adapted the primers to the needs of his students and - if he saw fit to do 
so - possibly also added some special dialogues, for instance about excessive drinking. Maybe the teacher had caught a student drinking or heard that he was drinking on a regular basis and wanted to exert a positive influence on him. In these instances, the primers functioned as a medium for the prevention of alcoholism and can be said to have conveyed a certain moral message, because in a society where alcohol drinking was ubiquitous, younger bannermen were undoubtedly exposed by friends or family to the many dangers of drinking.

However, there is more to these primers than just the quaint moral message. Primers also presented young bannermen with two extremes of banner life: stern military training on the one hand, and merry drinking sessions on the other hand. This stark contrast between sober archery talk and intoxicated bannermen neglecting their duties is striking. However, I believe that this was daily business for the young banner students. I even suggest that this at times slightly theatrical depiction can be understood as a form of self-parody, a mechanism to cope with what was an all-too-common phenomenon. At a time when a bannerman's identity was no longer shaped by military victories and when drinking was so widespread and public, why not turn something negative in something positive and laugh at oneself? The humorous undertone is mostly conveyed by the lively discussions, the very colloquial style of language, and the stereotypical depiction of the inebriated bannermen. The compilers of these primers also did not shy away from using occasional profanities to spice things up. This renders the primers much more entertaining, and I am convinced that the dialogues also were amusing to the banner students. This undoubtedly also increased their interest in the language at a time when most of them are believed to have grown up with Chinese as a first language and for whom Manchu was a second and probably bookish-seeming language. However, these stereotypical depictions of drunken bannermen are also problematic in that they trivialize alcoholism and portray it as something normal. The fact that these dialogues are entertaining only exacerbates this, just like the overused and trite moral messages. By reading these dialogues repeatedly, some of the banner students undoubtedly became numb to the dangers of drinking and possibly even internalized that drinking was an intrinsic part of banner culture. There is no gainsaying that this effect was completely at odds with the original educative function of the primers.

Instances of tobacco smoking are also frequent in the primers, albeit to a far lesser degree than drinking. Unlike alcohol, smoking is mostly portrayed as a recreational activity, and there is only one instance where a bannerman speaks out against it and ascribes the symptoms his friend is experiencing to excessive tobacco smoking. There is, however, no moral censure of tobacco smoking in the primers, and it is not portrayed as having detrimental effects on society. The court possibly considered tobacco smoking as a lesser evil compared to alcohol drinking and rampant opium smoking. Interestingly, there is no direct mention of opium smoking in any primer I have come across so far. 
The primers were presumably written around 1858 , a time when opium smoking was a serious problem for the court. Hence the question arises why there were no examples included in the primers to warn young bannermen of its dangers. A possible explanation would be that the court did not want to emphasize the ineffectivenss of some of its measures against opium addiction. Another, less plausible, theory, is that dambagu was sometimes used as a euphemism to indirectly refer to yarsi dambagu, "opium." However, this is mere conjecture on my part, as I have not found any textual examples for this yet.

A few final remarks on primers as historical sources are in order. Considering their well-balanced content and their various functions, they can justly be referred to as an amalgamation of different genres: textbooks, manuals, diaries, and even alcoholism prevention leaflets. Some occasional episodes are also interwoven with each other and thus resemble a short novel. This genre appears extremely adaptable, which is probably why it was so extensively used in Manchu language teaching even until after the fall of the Qing dynasty. ${ }^{42}$ Dismissing the primers as a mere medium to promulgate virtues associated with the Manchu Way such as archery, horsemanship, or frugality would therefore sell them short and only provide an incomplete picture.

\section{Bibliography}

\section{Primary Sources}

Li Shizhen 李时珍. Bencao gangmu 本草纲 [Compendium of Materia Medica]. Beijing: Renmin weisheng chubanshe, 1982.

Manbun rōtō 滿文老檔 [The Old Manchu Archives]. Ed. Kanda Nobuo 神田信夫 et al. 7 vols. Tokyo: Tōyō bunko, 1955-1963.

Walravens, Hartmut. Chinesische und mandjurische Handschriften und seltene Drucke. Wiesbaden: Franz Steiner Verlag, 2009.

Yongzheng Emperor 雍正. Shizongxian huangdi shangyu baqi 世宗憲皇帝上諭八 [Imperial Edicts on the Eight Banners of the Shizong Emperor of the Qing]. Accessed March 10, $2018 . \quad$ https:// ctext.org/wiki.pl?if=gb\&chapter=899596\&searchu=\%E9\%85\%92.

Zhang Boying 張伯英 and Wan Fulin 萬福麟. Heilongjiang zhigao 黑龍江志稿 [Chroniclesof Heilongjiang]. Beiping: Wenhai chubanshe, 1932.

42. Aixin Jueluo, “Tantang Qingdai de Manyu jiaoxue," 43-44. 


\section{Secondary Sources}

Aixin Jueluo Yingsheng 爱心觉罗瀛生. “Tantan Qingdai de Manyu jiaoxue” 谈谈清代的满语教 学 [Conversations about Manchu language classes in the Qing dynasty]. Manzu yanjiu 满族研究 1990.3: 43-49.

Baumler, Alan. The Chinese and Opium under the Republic: Worse than Floods and Wild Beasts. Albany: State University of New York Press, 2007.

Beinfield, Harriet, and Efrem Korngold. Traditionelle Chinesische Medizin: Grundlagen, Typenlehre, Therapie. München: Deutscher Taschenbuch Verlag, 2009.

Benedict, Carol. Golden-Silk Smoke: A History of Tobacco in China, 1550-2010. Berkeley: University of California Press, 2011.

Chen Jianwei 陈见微. “Qingdai Dongbei minjian de jiu wenhua” 清代东北民间的酒文 [The Drinking Culture of the People from China's Northeast during the Qing Dynasty]. Jilin shifan xueyuan xuebao 吉林师范学院学报 1996.1: 16-21.

Crossley, Pamela Kyle. Orphan Warriors: Three Manchu Generations and the End of the Qing World. Princeton: Princeton University Press, 1990.

Di Cosmo, Nicola. The Diary of a Manchu Soldier in Seventeenth-century China: My Service in the Army, by Dzengšeo. London: Routledge, 2006.

Elliott, Mark C. The Manchu Way: The Eight Banners and Ethnic Identity in Late Imperial China. Stanford: Stanford University Press, 2001.

Hames, Gina. Alcohol in World History. London: Routledge, 2012.

Lao She 老舍. Zheng hongqi xia 正紅旗下 [Beneath the Plain Red Banner]. Tianjin: Tianjin renminchubanshe, 2017.

Liu Xiaomeng 刘小萌. Qingdai Beijing qiren shehui 清代北京旗人社会 [Beijing Banner Society in the Qing Dynasty]. Beijing: Zhongguo shehui kexue chubanshe, 2008.

Lü Ping 吕萍. “Manzu saman jisi yu jiu” 满族萨满祭祀与酒 [Manchu Shamanistic Offerings and the Role of Alcohol]. Minzu yanjiu 满族研究 2007.1: 100-4.

McCaffrey, Cecily. "From Chaos to a New Order: Rebellion and Ethnic Regulation in Late Qing Inner Mongolia." Modern China 37.5 (September 2011): 528-61.

Naquin, Susan, and Evelyn S. Rawski. Chinese Society in the Eighteenth Century. New Haven: Yale University Press, 1987.

Norman, Jerry. A Comprehensive Manchu-English Dictionary. Cambridge, Mass.: Harvard University Asia Center, 2013.

Olivova, Lucie. "Tobacco Smoking in Qing China." Asia Major, 3d ser., 18.1 (2005): 225-60.

Pang, Tatjana A. Schriftliche mandschurische Quellen zur Geschichte und Kultur des Qing-Reiches des 17. und 18. Jahrhunderts. Wiesbaden: Harrassowitz Verlag, 2015.

Smith, Norman. Intoxicating Manchuria: Alcohol, Opium, and Culture in China's Northeast. Vancouver: UBC Press, 2012.

Stary, Giovanni. Emu Tanggü Orin Sakda-i Gisun Sarkiyan - Erzählungen der 120 Alten. Wiesbaden: Harrassowitz Verlag, 1983.

Yin Huihe 印会河. Zhongyi jichu lilun 中医基础理论 [The Basics of Traditional Chinese Medicine]. Shanghai: Shanghai kexue jishu chubanshe, 2007. 